\title{
PENGARUH BERBAGAI DOSIS TAWAS TERHADAP KEKERUHAN AIR SUMUR GALI DI DESA DUKUHLO RT 1 RW 6 KEC. LEBAKSIU KAB. TEGAL TAHUN 2016
}

\author{
Nur Amalia ${ }^{1)}$, Hari Rudijanto I.W. ${ }^{2)}$ \\ Jurusan Kesehatan Lingkungan, Politeknik Kesehatan Kemenkes Semarang \\ Jl.Raya Baturaden KM 12 Purwokerto, Indonesia
}

\begin{abstract}
Abstrak
Air merupakan salah satu kebutuhan pokok hidup manusia dan makhluk hidup lainnya, bahkan dalam tubuh manusia hampir 70\% berat badan terdiri dari unsur air. Permasalahan yang timbul dalam pemenuhan penyediaan air bersih adalah kualitas air tanah yang digunakan masyarakat kurang memenuhi syarat sebagai air bersih. Oleh karena itu setiap air bersih yang digunakan harus memenuhi syarat kualitas air bersih salah satunya yaitu air tidak berwarna atau tidak keruh. Metode yang dapat digunakan untuk mengurangi kekeruhan adalah dengan pemberian tawas. Tujuan penelitian ini adalah untuk mengetahui dosis tawas $10 \mathrm{mg} / \mathrm{l}, 20 \mathrm{mg} / \mathrm{l}, 30 \mathrm{mg} / \mathrm{l}$, dan $40 \mathrm{mg} / \mathrm{l}$ terhadap penurunan kekeruhan air sumur gali. Jenis penelitian ini adalah Pre Experiment dengan pendekatan Pre and Post Test Design Non Randomized. Hasil penelitian menunjukkan kekeruhan air sumur gali setelah perlakuan dengan dosis $10 \mathrm{mg} / \mathrm{l}$ rata-rata 12,6 NTU, $20 \mathrm{mg} / \mathrm{l}$ rata-rata 9,6 NTU, $30 \mathrm{mg} / \mathrm{l} \mathrm{rata-rata} 9 \mathrm{NTU}$, 40 mg/l rata-rata 6,5 NTU. Nilai pH air sumur gali setelah perlakuan rata-rata 4,3-5,6. Suhu air sumur gali setelah perlakuan rata-rata 27,6oC-28,16oC. Disimpulkan ada pengaruh yang signifikan terhadap pemberian tawas dalam menurunkan kekeruhan air sumur gali pada pemberian tawas dengan dosis 20 mg/l dengan hasil kekeruhan ratarata 9,6 NTU. Pemilik air sumur gali dengan kualitas air keruh dapat menerapkan hasil penelitian ini untuk mengurangi kekeruhan air sumur gali, dengan cara mencampurkan tawas dalam air, aduk terus pastikan tawas larut dalam air, yang selanjutnya masukkan larutan tawas ke dalam air sumur gali.
\end{abstract}

Kata kunci $\quad$ : kekeruhan, tawas, air sumur gali

\begin{abstract}
Water is one of the basic necessities of human life and other living creatures, even in the human body is almost $70 \%$ of body weight consist of water element. The problems that arise in meeting water supply is groundwater quality used less qualified people as clean water. Therefore, any water used must meet the requirements of water quality one of them that the water is colorless or turbid. The method can be used to reduce turbidity is by giving alum. The purpose of the study was to determine the alum dose of $10 \mathrm{mg} / \mathrm{l}, 20 \mathrm{mg} / \mathrm{l}, 30 \mathrm{mg} / \mathrm{l}, 40$ $\mathrm{mg} / \mathrm{l}$ to the reduction of water turbidity dug wells. This type of research is a Pre Experiment with approaches Pre and Post Test Non Randomized Design. The result obtained are the levels after treatment with a dosage $10 \mathrm{mg} / \mathrm{l}$ on average 12,6 NTU, at a dosage $20 \mathrm{mg} / \mathrm{l}$ on average 9,6 NTU, at a dosage $30 \mathrm{mg} / \mathrm{l}$ on average $9 \mathrm{NTU}$, at a dosage 40 $\mathrm{mg} / \mathrm{l}$ on average 6,5 NTU. Value of pH after treatment on average 4,3-5,6. Value of temperature after treatment on average 27,6 oC - 28,16 oC. The conclusion is significant difference in the administration of alum with decreased levels of turbidity in the alum dose $20 \mathrm{mg} / \mathrm{l}$ which decreased turbidity on average 9,6 NTU. The owners dug with murky water quality can apply these result to reduce turbidity levels.
\end{abstract}

Key words : $\quad$ turbidity, alum, water walls

\section{PENDAHULUAN}

Air merupakan salah satu kebutuhan pokok hidup manusia dan makhluk hidup lainnya, bahkan dalam tubuh manusia hampir $70 \%$ berat badan terdiri dari unsur air. Organisasi Kesehatan Dunia (WHO) menetapkan kebutuhan air per orang per hari untuk hidup sehat 60 liter di daerah pedesaan dan 150 di daerah perkotaan. Kebutuhan tersebut harus mencakup segi kuantitas dan kualitas, oleh karena itu pertimbangan dari berbagai aspek perlu

1) Email : nuramalia12lp@yahoo.com

2) Email : hariokey2000@yahoo.com diperhatikan sebagai dasar perencanaan penyediaan air yang memenuhi syarat, baik aspek tersebut sebagai factor pendukung maupun penghambat (Sanropie, et al, 1984) Permasalahan yang timbul dalam pemenuhan penyediaan air bersih adalah kualitas air tanah yang digunakan masyarakat kurang memenuhi syarat sebagai air bersih. Air yang layak diminum mempunyai persyaratan fisik, kimia dan bakteriologis, dan merupakan satu kesatuan, jadi jika ada salah satu parameter air yang tidak memenuhi 
syarat, maka air tersebut tidak layak untuk diminum (Said dan Wahjono, 1999, h.2). Masyarakat menggunakan air untuk memasak, mencuci, mandi, dan membersihkan kotoran yang ada disekitar rumah. Selain untuk memenuhi kebutuhan masyarakat. Air juga dibutuhkan untuk memenuhi kebutuhan pertanian, pemadam kebakaran, tempat rekreasi, transportasi, ekonomi, ibadah keagamaan dan industri (Nusa Idaman Said, 2001). Sumber air yang digunakan untuk memenuhi kebutuhan masyarakat di Desa Dukuhlo RT 1 RW 6 Kecamatan Lebaksiu Kabupaten Tegal berasal dari air tanah dengan sarana air bersih berupa sumur gali. Kebutuhan akan air bersih di daerah pedesaan dan pinggiran kota untuk air minum, memasak, mencuci dan sebagainya harus diperhatikan.

Berdasarkan teknik pengolahan air bersih salah satu cara untuk menurunkan kekeruhan adalah dengan pemakaian tawas, dengan dasar teori tersebut peneliti mencoba melakukan pengurangan kekeruhan dengan pemakaian tawas dengan berbagai dosis yang berbeda. Tawas sebagai bahan koagulan ternyata lebih dikenal masyarakat karena mempunyai nilai ekonomis yang tinggi, mudah didapat serta mudah penyimpanannya.

Masyarakat di Desa Dukuhlo RT 1 RW 6 Kecamatan Lebaksiu Kabupaten Tegal menggunakan sarana sumur gali untuk mendapatkan air bersih. Berdasarkan survey yang telah dilakukan air sumur gali di beberapa rumah secara fisik belum memenuhi persyaratan kesehatan karena air tersebut berwarna keruh, sedangkan air yang memenuhi syarat kesehatan diantaranya yaitu air tidak berwarna. Hal ini dapat dikarenakan pembangunan sumur gali dekat dengan sumber pencemar (jarak kurang dari $10 \mathrm{~m}$ ). Sumber pencemar diantaranya yaitu sungai. Berdasarkan keluhan masyarakat di desa Desa Dukuhlo RT 1 RW 6 Kecamatan Lebaksiu Kabupaten Tegal mengenai air sumur gali yang berwarna keruh, dan air yang keruh tersebut digunakan untuk kebutuhan sehari-hari. Melihat dari permasalahan yang ada di lapangan, maka peneliti ingin mengadakan penelitian Karya Tulis Ilmiah dengan judul: "Pengaruh berbagai Dosis Tawas terhadap Kekeruhan Air Sumur Gali di Desa Dukuhlo RT 1 RW 6 Kecamatan Lebaksiu Kabupaten Tegal tahun 2016”. Tujuan penelitian ini yaitu sebagai berikut :

1. Mengukur $\mathrm{pH}$ air sumur gali sebelum dan sesudah perlakuan

2. Mengukur suhu air sumur gali sebelum dan sesudah perlakuan

3. Mengukur kekeruhan air sumur gali sebelum dan sesudah perlakuan (dengan dosis tawas 10 $\mathrm{mg} / \mathrm{l}, 20 \mathrm{mg} / \mathrm{l}, 30 \mathrm{mg} / \mathrm{l}, 40 \mathrm{mg} / \mathrm{l}$ )

4. Menganalisis pengaruh berbagai dosis tawas terhadap penurunan kekeruhan air sumur gali sebelum dan setelah perlakuan

\section{METODE PENELITIAN}

Jenis penelitian ini adalah jenis penelitian Pre Experiment, dengan metode pre-test and post test design, dengan maksud untuk mengetahui ada atau tidaknya perbedaan penggunaan dengan dosis tawas terhadap penurunan kekeruhan air sumur gali, dalam penelitian ini variabel terikatnya adalah kekeruhan air sumur gali pada sampel sebelum dan sesudah pengolahan dengan menggunakan dosis tawas. Variabel bebas dalam penelitian ini adalah bahan kimia yaitu tawas. Variabel pengganggu dalam penelitian ini adalah $\mathrm{pH}$ air sumur gali, suhu air sumur gali

Populasi penelitian ini adalah seluruh air sumur gali yang keruh di Desa Dukuhlo RT 1 RW 6, Kecamatan Lebaksiu, Kabupaten Tegal. Berdasarkan data yang didapatkan terdapat 3 sumur gali yang airnya keruh, sehingga populasi untuk penelitian ini adalah sebanyak 3 sumur gali yang airnya keruh. Sampel pada penelitian ini adalah salah satu air sumur gali responden.

Data hasil penelitian ditabulasi untuk selanjutnya dianalisis menghitung nilai mean dan prosentase yang selanjutnya dibandingkan kekeruhan air sumur gali setelah pemberian tawas guna memperoleh gambaran yang paling efektif dalam menurunkan kekeruhan air sumur gali. Data hasil penelitian ditabulasi untuk selanjutnya dianalisis menggunakan program SPSS dengan uji statistic Paired t Test.

\section{HASIL DAN PEMBAHASAN}

\section{Gambaran Umum}

Dukuhlo merupakan salah satu desa yang berada di Kecamatan Lebaksiu, Kabupaten Tegal, Provinsi Jawa Tengah. Luas wilayah Desa Dukuhlo menurut penggunaan, konversi : $1 \mathrm{Ha}=10.000 \mathrm{~m} 2$ atau $1 \mathrm{~m} 2$ $=0,0001 \mathrm{Ha}$. Tanah sawah irigasi teknis memiliki luas 137,5 Ha. Batas wilayah Desa Dukuhlo, yaitu : Sebelah utara : Desa Pendawa Kec. Dukuhturi Sebelah selatan : Desa Kajen Kec. Lebaksiu Sebelah timur : Desa Pener Kec. Pangkah Sebelah barat : Desa Jatimulya Kec. Lebaksiu Sumber Daya Manusia (SDM) di Desa Dukuhlo, yaitu : Jumlah laki-laki : 1949 orang Jumlah perempuan : 1940 orang Jumlah total : 3889 orang Jumlah KK : 1044 KK

Sumber daya air yang dimiliki di Desa Dukuhlo, yaitu : sungai adalah salah satu jenis sumber air yang ada, terdapat 3 sungai, kondisi sungai mengalami pendangkalan atau pengendapan lumpur tinggi, serta air sungai keruh. Sarana sumber air bersih yang digunakan sebagian besar masyarakat Desa Dukuhlo adalah sumur gali. Jumlah sumur gali yang dimiliki di Desa Dukuhlo yaitu 800 sumur gali, dengan kondisi sumur gali ada yang memenuhi persyaratan kesehatan dan ada yang belum memenuhi syarat. Sumber air minum yang sebagian besar masyarakat gunakan adalah bersumber pada Mata Air (MA), 
Sumur Gali (SGL), Sumur Pompa Tangan (SPT), dan Depot Air Minum Isi Ulang (DAMIU).

\section{Gambaran Khusus}

1. Pengukuran $\mathrm{pH}$ air sumur gali

Pengukuran kadar $\mathrm{pH}$ menggunakan $\mathrm{pH}$ stick. Data hasil pengukuran $\mathrm{pH}$ air sumur gali sebelum dan sesudah perlakuan dapat dilihat pada tabel 4.2.

Tabel $4.2 \mathrm{pH}$ air sumur gali sebelum dan sesudah perlakuan dengan dosis tawas tahun 2016

\begin{tabular}{|c|c|c|c|c|c|c|}
\hline \multirow{3}{*}{ No } & \multirow{3}{*}{ Sampel } & \multirow{3}{*}{ Sebelum } & \multicolumn{4}{|c|}{ Hasil pengukuran $\mathrm{pH}$} \\
\hline & & & \multicolumn{4}{|c|}{$\begin{array}{c}\text { Perlakuan dengan dosis } \\
\text { tawas (mg/l) }\end{array}$} \\
\hline & & & 10 & 20 & 30 & 40 \\
\hline 1. & 1 & 6 & 6 & 6 & 6 & 5 \\
\hline 2. & 2 & 6 & 6 & 6 & 5 & 4 \\
\hline 3. & 3 & 6 & 6 & 5 & 5 & 4 \\
\hline & 1-rata & 6 & 6 & 5,6 & 5,3 & 4,3 \\
\hline
\end{tabular}

Data yang dapat dilihat pada tabel 4.2 berdasarkan hasil pengukuran, $\mathrm{pH}$ air sumur gali sebelum perlakuan $\mathrm{pH}$ rata-rata sebesar 6 dan sesudah perlakuan dengan pemberian tawas $\mathrm{pH}$ rata-rata sebesar 4,3 - 5,6. Berdasarkan hasil maka $\mathrm{pH}$ memenuhi persyaratan karena menurut PP No. 82 tahun 2001 tentang Pengelolaan Kualitas Air dan Pengendalian Pencemaran Air untuk parameter kimia yaitu nilai pH 6-9.

Derajat keasaman atau $\mathrm{pH}$, besaran $\mathrm{pH}$ berkisar dari 0 (sangat asam) sampai dengan 14 (sangat basa atau alkalis). Nilai pH kurang dari 7 menunjukkan lingkungan yang masam sedangkan nilai diatas 7 menunjukkan lingkungan yang basa (alkalin), sedangkan $\mathrm{pH}=$ 7 disebut sebagai netral.

2. Pengukuran suhu air sumur gali

Suhu udara dilingkungan pada saat itu adalah $26^{\circ} \mathrm{C}$. Data hasil pengukuran suhu sampel air sumur gali sebelum dan sesudah perlakuan dapat dilihat pada tabel 4.3

Tabel 4.3 Suhu air sumur gali sebelum dan sesudah perlakuan dengan dosis tawas tahun 2016

\begin{tabular}{|c|c|c|c|c|c|c|}
\hline \multirow{3}{*}{$\begin{array}{l}\mathbf{N} \\
0\end{array}$} & \multirow{3}{*}{$\begin{array}{c}\text { Sa } \\
\text { mpe } \\
1\end{array}$} & \multirow{3}{*}{$\begin{array}{c}\text { Sebel } \\
\text { um }\end{array}$} & \multicolumn{4}{|c|}{ Hasil penguluran subu ('C) } \\
\hline & & & \multicolumn{4}{|c|}{$\begin{array}{l}\text { Perlakuan dengan dosis tawas } \\
\text { (mg/1) }\end{array}$} \\
\hline & & & 10 & 20 & 30 & 40 \\
\hline 1. & 1 & 27 & 29 & 29 & 29 & 28 \\
\hline 2. & 2 & 27 & 27 & 27 & 27 & 27 \\
\hline 3. & 3 & 28 & 29 & 29 & 28,5 & 28 \\
\hline Rat: & & 27,3 & 28,3 & 28,3 & 28,16 & 27,6 \\
\hline
\end{tabular}

Tabel 4.3, pengukuran nilai suhu dapat diketahui bahwa rata-rata sebelum perlakuan dengan tawas adalah $27,3{ }^{\circ} \mathrm{C}$ dan sesudah perlakuan dengan pemberian tawas adalah 27,6 ${ }^{\circ} \mathrm{C}-28,16{ }^{\circ} \mathrm{C}$. Suhu udara dilingkungan pada saat itu adalah $26^{\circ} \mathrm{C}$. Berdasarkan hasil tersebut maka suhu yang diperoleh memenuhi syarat karena menurut PP No. 82 tahun 2001 tentang
Pengelolaan Kualitas Air dan Pengendalian Pencemaran Air untuk parameter suhu $\pm 3^{\circ} \mathrm{C}$ dari suhu udara.

Menurut Basuki Hardjojo (2008, h:3.4) suhu air normal adalah suhu air yang memungkinkan makhluk hidup dapat melakukan metabolisme dan berkembang biak. Suhu merupakan faktor fisik yang sangat penting di air, sebab bersama-sama dengan zat atau unsur yang terkandung di dalamnya akan menentukan massa jenis air, dan bersama-sama dengan tekanan dapat digunakan untuk menentukan kejenuhan air.

3. Pengukuran kekeruhan air sumur gali

Tabel 4.4 kekeruhan air sumur gali sebelum dan sesudah perlakuan dengan dosis tawas tahun 2016

\begin{tabular}{lcccccc}
\hline & & \multicolumn{3}{c}{$\begin{array}{c}\text { Hasil pengukuran } \\
\text { kekeruhan (NTU) }\end{array}$} \\
\cline { 3 - 7 } No Sampel & Sebelum & \multicolumn{2}{c}{$\begin{array}{l}\text { Perlakuan dengan } \\
\text { dosis tawas (mg/) }\end{array}$} \\
\cline { 3 - 7 } & & $\mathbf{1 0}$ & $\mathbf{2 0}$ & $\mathbf{3 0}$ & $\mathbf{4 0}$ \\
\hline 1. & 1 & 15 & 13 & 10 & 9 & 7 \\
2. & 2 & 15 & 13 & 9 & 9 & 7 \\
3. & 3 & 15 & 12 & 10 & 9 & 5 \\
\hline \multicolumn{2}{r}{ Rata-rata } & 15 & 12,6 & 9,6 & 9 & 6,5 \\
\hline
\end{tabular}

Berdasarkan hasil pengukuran kekeruhan air sumur gali dapat dilihat pada tabel 4.4, dapat diketahui bahwa kekeruhan sebelum pemberian tawas adalah 15 NTU dan sesudah perlakuan dengan pemberian tawas nilai kekeruhan ratarata yang diperoleh adalah 6,5 NTU - 12,6 NTU. Berdasarkan hasil tersebut maka kekeruhan air sumur gali belum memenuhi syarat karena menurut Permenkes RI No.416 tahun 1990 tentang Persyaratan Kualitas Air Bersih untuk parameter kekeruhan kadar maksimum yang diperoleh adalah 5 NTU.

4. Analisis Paired T Test

Analisis bivariat dilakukan menggunakan uji beda dua mean data berpasangan satu sampel (paired $t$ test (pre - post)). Analisis ini dilakukan untuk mengetahui perbandingan kekeruhan pada air sumur gali sebelum dan setelah diberi perlakuan dengan menggunakan tawas. Hipotesis yang digunakan adalah $\mathrm{Ho}$ yaitu tidak ada perbedaan pengaruh pemberian dosis tawas.

Tabel 4.5 Hasil Uji Statistik Paired T Test

\begin{tabular}{llll}
\multicolumn{5}{c}{ (Pre - Post) } \\
\hline No & Dosis tawas & $\alpha(0,05)$ & Ket. \\
\hline 1. & $10 \mathrm{mg} / 1$ & 0,20 & Tak signifikan \\
2. & $20 \mathrm{mg} / 1$ & 0,04 & signifikan \\
3. & $30 \mathrm{mg} / 1$ & - & $\begin{array}{l}\text { Tidakk dapat } \\
\text { dianalisis }\end{array}$ \\
4. & $40 \mathrm{mg} / 1$ & 0,06 & Tak signifikan \\
\hline
\end{tabular}

Keterangan :

a. Dosis tawas $10 \mathrm{mg} / \mathrm{l}$, nilai signifikan sebesar 0,20, maka Ho diterima berarti tidak ada perbedaan pengaruh setelah pemberian tawas dengan dosis $10 \mathrm{mg} / \mathrm{l}$ 
b. Dosis tawas $20 \mathrm{mg} / \mathrm{l}$, nilai signifikan sebesar 0,04, maka Ho ditolak, sehingga ada pengaruh pemberian dosis tawas

c. Dosis tawas $30 \mathrm{mg} / \mathrm{l}$, ada perbedaan pengaruh setelah pemberian tawas dengan dosis $30 \mathrm{mg} / \mathrm{l}$

d. Dosis tawas $40 \mathrm{mg} / \mathrm{l}$, nilai signifikan sebesar 0,06, maka Ho diterima, berarti tidak ada perbedaan pengaruh setelah pemberian tawas dengan dosis $40 \mathrm{mg} / \mathrm{l}$

5. Analisis Anova

Analisis dilakukan menggunakan uji ANOVA (Oneway Anova) untuk menganalisis pengaruh pemberian tawas dosis $10 \mathrm{mg} / \mathrm{l}, 20$ $\mathrm{mg} / \mathrm{l}, 30 \mathrm{mg} / \mathrm{l}, 40 \mathrm{mg} / \mathrm{l}$ dalam menurunkan kekeruhan air sumur gali di Desa Dukuhlo RT 1 RW 6 Kec. Lebaksiu Kab. Tegal. Tabel hasil analisis data dapat dilihat pada tabel berikut ini : Tabel 4.6 Hasil Analisis Homogenitas

\begin{tabular}{llll}
\multicolumn{2}{c}{ Anova } & & \\
\hline Levene & df & df & Sig \\
statistic & 1 & 2 & \\
\hline 7.111 & 3 & 8 & .012
\end{tabular}

Berdasarkan tabel 4.6 Test Homogeineity Variance diperoleh nilai signifikan 0,012 ini berarti lebih kecil dari 0,05 (nilai $\alpha$ ), sehingga tidak memenuhi persyaratan untuk uji Anova, untuk itu diteruskan menggunakan uji Kruskall Wallis.

Tabel 4.7 Hasil Analisis Kruskall Wallis Test

\begin{tabular}{ll}
\hline & Penuruman \\
\hline Chi- & 10275 \\
square & \\
Df & 3 \\
Assymp. & .016 \\
Sig & \\
\hline
\end{tabular}

Berdasarkan data hasil uji analisis dengan uji Kruskall Wallis yang tertera pada tabel 4.7 diperoleh nilai signifikan 0,016 ini berarti lebih kecil dari 0,05 (nilai $\alpha$ ), sehingga ada pengaruh yang signifikan.

\section{SIMPULAN DAN SARAN}

\section{Simpulan}

1. $\mathrm{pH}$ air sumur gali sebelum rata-rata sebesar 6 dan sesudah perlakuan rata-rata sebesar 4,3 5,6

2. Suhu air sumur gali rata-rata sebelum perlakuan dengan tawas adalah $27,3{ }^{\circ} \mathrm{C}$ dan sesudah perlakuan dengan pemberian tawas adalah 27,6 ${ }^{\circ} \mathrm{C}-28,16{ }^{\circ} \mathrm{C}$

3. Kekeruhan air sumur gali sebelum pemberian tawas adalah 15 NTU dan sesudah perlakuan pada dosis tawas $10 \mathrm{mg} / \mathrm{l}$ rata-rata sebesar 12,6
NTU, pada dosis tawas $20 \mathrm{mg} / \mathrm{l}$ rata-rata sebesar 9,6 NTU, pada dosis tawas $30 \mathrm{mg} / \mathrm{l}$ rata-rata sebesar 9 NTU, pada dosis tawas $40 \mathrm{mg} / \mathrm{l}$ ratarata sebesar 6,5 NTU

4. Ada pengaruh yang signifikan dari pemberian tawas terhadap penurunan kekeruhan air sumur gali, yaitu pada pemberian tawas dengan dosis 20 mg/l, nilai signifikan 0,04 maka Ho ditolak.

\section{Saran}

1. Pemilik sumur gali dengan kualitas air keruh, dalam menurunkan kekeruhan dapat dengan cara memberi tawas sebagai media alternatif, cara pemberian tawas untuk menjernihkan air sumur adalah dengan mencampurkan tawas dengan sedikit air ( \pm 5 liter). Jika anda memakai tawas bongkahan, terlebih dahulu hancurkan menjadi lebih lembut. Aduk aduk terus, pastikan tawas sudah larut dalam air. Cukup 3-5 sendok makan full untuk 1000 liter air dalam sumur. Selanjutnya masukkan larutan campuran tawas dengan air ke dalam sumur

2. Air sumur gali yang keruh dapat diendapkan terlebih dahulu di dalam penampung air seperti container sebelum air digunakan untuk keperluan sehari-hari.

3. Kekeruhan dapat pula dikurangi dengan pemakaian filter pada kran seperti kain saring, sehingga partikel-partikel yang menyebabkan air sumur gali tersaring.

4. Saran bagi peneliti selanjutnya, penurunan kekeruhan air sumur gali dengan pemberian koagulan selain tawas, untuk mengahasilkan air bersih dengan nilai kekeruhan yang diperbolehkan 5 NTU.

\section{DAFTAR PUSTAKA}

Alaerts G, Sri Sumestri Santika, 1987, Metode Penelitian Air, Surabaya: Usaha Nasional

Aris Santjaka, 2008, Bio Statistik, Purwokerto: Global Intemusa

Aris Santjaka, 2011, Statistika untuk Penelitian Kesehatan 1, Yogyakarta: Nuha Medika

Basuki Hardjojo, 2008, Pengukuran dan Analisis Kualitas Air, Jakarta: Universitas Terbuka

Depkes RI, 1990, Permenkes No. 416/Menkes/Per/IX/1990, Tentang SyaratSyarat dan Pengawasan Kualitas Air, Jakarta: Depkes RI

Djamaludin Ramlan, 2013, Dasar Statistik Penelitian, Purwokerto: UPT Percetakan dan Penerbitan

Djamaludin Ramlan, 2013, Petunjuk Praktis Penulisan Penelitian Eksplanatif, 
Purwokerto: UPT Percetakan dan Penerbitan

Djasio Sanropie et al, 1984, Penyediaan Air Bersih, Proyek Pengembangan Pendidikan Tenaga Sanitasi Pusat Pusat Pendidikan dan Latihan Pegawai Departemen Kesehatan RI

http://jadibersih.com/, “Cara Menjernihkan Air Sumur yang Kuning Keruh dan Kotor”, (online) diakses pada 14 Januari 2016 pukul 16:00 WIB

http://litbang.patikab.go.id/index.php?view=article \&catid=166, "Konstruksi dan Kualitas Air Sumur Gali”, (online) diakses pada 13 Januari 2016 pukul 14:16 WIB

http://www.saringanair.com/news/2/, “Takaran Tawas dan Kapur Gamping untuk Penjernih Air”, (online) diakses pada 13 Januari 2016 pukul 15:00 WIB

Kemenkes RI, (1994/1995), Petunjuk Inspeksi Sanitasi Sarana Air Bersih, Jawa Tengah: Proyek Pengawasan Sarana Air Bersih Propinsi Jawa Tengah

Marsum, 1997, Diktat Praktikum Kimia Lingkungan, Purwokerto: Unit Laboratorium AKL Depkes Purwokerto

Mohammad Nazir, 1998, Metode Penelitian, Jakarta: Ghalia Indonesia

Nusa Idaman Said, 1999, Kesehatan Masyarakat dan Teknologi Peningkatan Kualitas Air, Jakarta: BPPT

Pemerintah Kabupaten Tegal, 2013, Buku Daftar Isian Potensi Desa dan Kelurahan serta Daftar Isian Tingkat Perkembangan Desa dan Kelurahan, Badan Pemberdayaan Masyarakat dan Desa: Kabupaten Tegal

\section{Peraturan Menteri Kesehatan RI No 492/MENKES/PER/IV/2010, Persyaratan Air Minum}
Peraturan Pemerintah No. 42 tahun 2008, Pengelolaan Kualitas Air dan Pengendalian Pencemaran Air, Jakarta: Depkes RI

Suparmin, 2011, Teori dan Praktik Pengolahan Air Minum, Purwokerto: Yayasan Sanitarian Banyumas (YASAMAS)
S.Purwanto, dkk, 1997, Buku Pedoman Praktek, Purwokerto: Depkes RI Akademi Kesehatan Lingkungan Purwokerto

Tjokrokusumo, 1995, Pengantar Konsep Teknologi Bersih Khusus Pengelolaan dan Pengolahan Air, Yogyakarta: Sekolah Tinggi Teknik Lingkungan YLH

Totok Sutrisno, dkk, 2006, Teknologi Penyediaan Air Bersih, Jakarta: PT Rineka Cipta

Tri Cahyono, 2014, Pedoman Penulisan Proposal Penelitian dan Karya Tulis Ilmiah / Skripsi, Purwokerto: Kementerian Kesehatan Republik Indonesia Politeknik Kesehatan Kemenkes Semarang Jurusan Kesehatan Lingkungan Purwokerto 